\title{
Loss of Social Belonging, Displacement and Social Exclusion in the Neighborhood: Urban Redevelopment in Sarigol, Istanbul, Turkey
}

\author{
Mahallede Aidiyet Duygusunun Kaybı, Yerinden Edilme ve Sosyal Dışlanma: \\ Sarıgöl'de Kentsel Dönüşüm, İstanbul, Türkiye
}

\author{
İlkim MARKOÇ, Candan ÇINAR
}

\section{ABSTRACT}

Urban redevelopment primarily occurs in shantytowns and the squatters are the most affected by it. The redevelopment projects can potentially lead to countless problems within the neighborhood due to the spill-over effect it has on the social fabric of a community. The main objective of this article is to analyze one of the redevelopment site, Sarigol, in Istanbul and three of those problems caused by the urban redevelopment: loss of social belonging, displacement and social exclusion. According to numerous studies, the fundamental cause of social exclusion, regarded as loss of the sense of belonging and physical displacement, is that prior to urban redevelopment, the members of various socio-cultural and economic social classes were living together without any social integration. The town of Sarigol, which was chosen for fieldwork, was established as a shantytown in the 1950's and today, urban transformation continues there at full speed. In this research, in-depth interviews have been conducted in Sarigol and the effects of a changing social dynamic were analyzed with regard to residents' responses on urban redevelopment within the context of those concepts. To absorb the negative effects of the process, innovative changes have to be presented both for physical and social fabric of the neighborhood. In order to provide the social and economic integration, social bonds which allow new comers to gain their sense of belonging and enable stabiles to overcome their socio-cultural and economic differences have to be built.

Keywords: Displacement; neighborhood; Sarigol; social belonging; social exclusion; urban transformation.

Kentsel dönüşüm en çok gecekondu alanlarında gerçekleşmektedir. Bu süreçten en çok etkilenen grup ise gecekondululardır. Kentsel dönüşüm projeleri, mahallenin sosyal dokusunda değişime sebep olmasından dolayı pek çok sorunu beraberinde getirmektedir. Bu makalenin amacı, İstanbul'da bir dönüşüm alanı olan Sarıgöl'deki süreçte ortaya çıkan sorunları aidiyet kaybı, yerinden edilme ve sosyal dışlanma kavramları bağlamında ele almaktır. Bir çok çalışmaya göre sosyal dışlanma, aidiyet duygusu kaybı ve yerinden edilme süreçleri ile beraber gelişmektedir. Kentsel dönüşüm süreciyle birlikte farklı sosyo-kültürel ve ekonomik sınıflardan kişiler sosyal entegrasyon sağlanamadan bir arada yaşamak durumunda kalmaktadır. Alan çalışması için seçilmiş olan Sarıgöl, 1950'lerde yapılaşmanın başladığı bir gecekondu yerleşimidir ve günümüzde de Sarıgöl'de kentsel dönüşüm tüm hızıyla devam etmektedir. Alan araştırmasında derinlemesine görüşmeler yapılarak, değişen sosyal dinamiklerin analizi mahallelinin bu üç kavram için ifadeleri doğrultusunda gerçekleştirilmiştir. Kentsel dönüşüm sürecinin toplumdaki olumsuz etkilerinin azaltılabilmesi için mahallenin sadece fiziksel değil sosyal dokusu için de yenilikçi çözüm önerileri sunulmalıdır. Yeni gelenlerin mahalleye aidiyet duymalarını, kalanların ise sosyo-kültürel ve ekonomik farklılıkları aşmasını sağlayacak sosyal bağların kurulması ile sosyal ve ekonomik entegrasyon sağlanmalıdır.

Anahtar sözcükler: Yerinden edilme; mahalle; Sarıöl; aidiyet; sosyal dışlanma; kentsel dönüşüm.

Department of Architecture, Yıldız Tehnical University Faculty of Architecture, İstanbul, Turkey

Article arrival date: November 07, 2017 - Accepted for publication: December 13, 2017

Correspondence: Illkim MARKOÇ. e-mail: imarkoc@hotmail.com

@ 2018 Yıldız Teknik Üniversitesi Mimarlık Fakültesi - @ 2018 YIldız Technical University, Faculty of Architecture 


\section{Introduction}

Within the scope of this article, the changing fabric of the neighborhood under the auspices of urbanization is discussed in the context of social belonging, displacement and exclusion; whereas the legal and financial aspects of urbanization will not be addressed.

This article is generated from the doctoral thesis titled, "An Evaluation of Quality / Satisfaction Parameters within Housing Satisfaction: Sarigol" and investigates the perceptions of residents in different social groups of Sarigol neighborhood in order to demonstrate the diversity when defining social belonging, displacement and exclusion. The exploratory research was designed as a case study in Sarigol, Istanbul. The qualitative data provided in the article derives from in-depth interviews conducted in the field and the data is discussed in the context of social belonging, displacement and social exclusion. As a result of these discussions, it is revealed that urban redevelopment leads to not only physical changes in the affected area but also social changes. Deteriorated conditions in the affected area undoubtedly equates with social dissatisfaction among those who stayed after the process, as well as those who left and those who newly moved to the affected area. Presenting the situation is of great importance in relation to the interpretation of the social dimension of urban redevelopment.

The paper includes four major sections. The first section reviews the discussions about the main three concepts; social belonging, displacement and exclusion. The second section summarizes the history of Turkey's shantytowns starting from the times when urban redevelopment firstly became an issue. The third section discusses the case study within the context of the three concept of the article. At the final section, put forward the findings and contributions of the study in relation to existing literature.

\section{Overview of the Literature and Conceptual Framework}

In the process of housing redevelopment, housing mobility is actualized at a high rate. This situation comes with not only physical alterations but social changes, as well. This article discusses i) the social transformations underwent by the affected neighborhood and ii) the problems, those arise during the urban redevelopment process in the context of social belonging, displacement and social exclusion. First, the context of the place of the concepts in the literature is presented.

\section{Social Belonging}

As Seamon claimed in 1980, places do not have static characters and the meanings attached to those environments can be changed in parallel with the rhythm that they have. Simonsen's claims also support Seamon's in that the neighborhood is not a stagnant physical entity but an ongoing and contextual process. (Seamonsen, 2008).

As Gustafson claimed in 2008, having an emotional attachment to a certain place has maintained its importance for the urban residents of the globalized world, in which mobility is one of the most crucial features and mobility and social belonging are not differential. (Gustafson, 2008)

Studies on social belonging have shown that the sense of belonging is shaped in tandem with social distinctions and variations in resources. (Savage et al. 2010) In this sense, one can say that there are different causes for the formation of the sense of belonging among people from distinct social backgrounds while the concept is actually an ever-changing process in relation to both people and resources as Hummon, Gustafson and Lewicka also suggested. Furthermore, the meanings, traditions and history that people attach to certain places also affect the development of a sense of belonging. (Hummon, 1992; Gustafson, 2008; Lewicka, 2011).

According to Fallov et al. (Fallov, et al., 2013) there is a connection between the sense of social belonging and the length of inhabitancy. It can be argued that the significance of a place, experiences and traditions all have an effect on social belonging. (Gustafson, 2008).

According to the studies of Pinkster and Boterman the sense of belonging is intensified when residents feel a sense of familiarity with both their neighborhood and neighbors. The sense of belonging is affected by the sounds, smells, tastes and visual effects of the location where people live. (Pinkster and Boterman, 2017) That sense of social belonging may become a source of alienation during the transformation of the neighborhood. The transformation in the neighborhood's social fabric constitutes an impediment in terms of building new social bonds and a renewed sense of social belonging after the process. (Bailey et al., 2012).

\section{Displacement}

In the work published in 2008, Lees and Ley argue that the negative effects of displacement can be observed when middle-income groups move to the newly redeveloped low-income neighborhoods; adding that the most obvious negative impact of this is the displacement of lowincome groups. (Lees and Ley, 2008) Also, another risk of urban transformation projects for the low-income margin of society is the exclusionary effect of market conditions. The indirect displacement of people who preferred to stay in a particular place after the redevelopment process; due to economic exclusion, is another threat for the changing social fabric of a neighborhood. (Newman and Wyly, 2006).

The negative results of forced displacement in areas where there are high levels of involuntary housing mobil- 
ity are multi-dimensionally diversified. High levels of housing mobility lead to the deterioration of the social fabric and cause various problems for the residents of the neighborhood. (Tieskens and Musterd, 2013).

Urban sociology also studies the effects of displacement on those people who were forced to move involuntarily. Research is being conducted in order to take a critical look at state-led redevelopment projects and reveals the negative effects these projects have on the displaced persons. (Bridge, Butler and Lees, 2012) According to the research of Fried, Gans, Goetz, Kleit and Manzo, forced displacement as a result of urban redevelopment projects has a negative effect on the level of satisfaction among residents with regard to the housing and their social bonds within the community. (Fried, 1963; Gans, 1962; Goetz, 2002; Kleit, 2010; Manzo, 2013).

In the housing redevelopment process, displacement can occur either voluntarily or involuntarily. Clapham and Kintrea in their work analyzed the concepts of both voluntary and involuntary displacement within the scope of three key aspects. One of those aspects highlights the impacts of institutions and policymakers on displacement. Secondly, Clapham and Kintrea focused on the impact of class structure and ethnic and social exclusion as negative results of displacement. The third aspect stresses the fact that the individual choice of tenants has a dominant effect on displacement. (Clapham and Kintrea, 1984) Research conducted by Tieskens and Musterd presents empirical proof for these three aspects. According to the data, institutional and structural factors have the most primary influence on displacement while, nonetheless, the housing preferences of the tenants are also noticeable. (Tieskens and Musterd, 2013).

\section{Social Exclusion}

Social exclusion is a common concept within the disciplines of sociology, psychology, education, politics and economics. As stated in Silver's study, people who are excluded from a society are affected by the absence of "citizenship and legal equality, democratic participation, public goods, dominant nationality, livelihood, secure and permanent employment, earnings, property, credit or land, housing, minimal or prevailing consumption levels, education skills and cultural capital; the welfare state, race, family and sociability, humanity, respect, fulfillment and understanding." (Silver, 2014).

Many scholars defined the concept as a dynamic and multi-dimensional process. Popay equated the concept with unequal relations in terms of power, which are affected by each other in various dimensions. These aspects were classified in four primary layers; namely, the economic, political, social and cultural. The unequal division of rights and resources in one of the aforementioned layers between individuals or communities eventually leads to the exclusion of some parts of the society. (Popay, 2008).

Power and Wilson defined social exclusion also as a multifaceted procedure of social rupture, which creates a disconnection between residents, institutions, and in terms of social relations. (Power and Wilson, 2000) Upon being segregated from their social and bureaucratic ties, the socially excluded people are unable to continue their daily routine activities in their neighborhood. (Bossert, Dambrosio and Peragine, 2007) Furthermore, Robila stated that social exclusion is the direct opposite of social integration, which entails being a part of society. (Robila, 2006).

Bediz Yılmaz's study titled, "Entrapped in Multidimensional Exclusion: The Perpetuation of Poverty among Conflict-induced Migrants in an Istanbul Neighborhood," explained the social exclusion within the district of Tarlabasi, a redeveloped area in Istanbul, by emphasizing the processes of social exclusion in shantytowns of the city after a comprehensive literature review. She discussed the social exclusion of vulnerable parts of Tarlabasi, which is a historical neighborhood undergoing redevelopments with regards to social, political, spatial, economic and discursive dimensions. (Yilmaz, 2008).

Slater in his work published in 2009 discussed Marcuse's idea of exclusionary displacement as one of the most common types of urban social exclusion. Exclusionary displacement, as previously defined, includes ethnic, racial and income segment groups, which are excluded from their neighborhoods. (Marcuse, 1986; Slater, 2009).

The prices of real estate increase during periods of urban transformation. Furthermore, services in a neighborhood, which are shaped by the habits of the middle-high income bracket, have an exclusionary impact on the low-income group. Marginalized by new, socio-cultural fabrics of the neighborhood, low-income groups also face economic marginalization due to the increasing cost of housing. The monthly fees collected for services offered in housing sites create financial difficulties for low-income groups in terms of budgetary restrictions. In addition, the target markets of low- income groups for shopping are eliminated in these housing sites; forcing low-income members of the neighborhood to shop in areas that are designed for the middle-high income groups. This situation is one of the main, exclusive economic factors affecting the low-income groups. The economic difficulties for people who decide to stay in their respective areas throughout the transformation process are known as indirect displacement. These conditions lead to an ongoing change in the social fabric of the neighborhood. While low-income groups leave the site, middle-high income groups who are financially capable of fulfilling the new economic requirements flock to these redevelopment sites in a situation that is conceptu- 
alized as the exclusive impact of economic conditions on low-income groups. (Newman and Wyly, 2006; Atkinson, 2000; Freeman and Braconi, 2004).

Moreover, Adaman and Keyder's study conducted in six large cities of Turkey discussed the concept of social exclusion within three social dimensions. They argued that, some of those people who came to the city later on and could not comply with the challenges of urban life had to resort to illegal activities since they could not participate in work life due to their lower levels of education. This situation is considered as a crime threat for the newcomers. Thus, the levels of their education and their participation to the labor market constituted two of those dimensions. The last dimension, which they mentioned, was the social participation. The last dimension has a deep connection with distorted social fabric of the neighborhood. Therefore, these circumstances are a clear example of social exclusion within daily life in the neighborhood as Sarigol study addressed. Hence, newcomers expect residents to leave the site. (Adaman and Keyder, 2006).

\section{Housing Production and Urban Transformation} in Turkey

The modernization movement in Turkey's agricultural sector in the 1950s resulted in the labor power surplus within the capitalist agricultural production model and led to intense migration from rural to urban areas. However, it became a starting point for problems affecting both the state and the population because the state didn't provide housing for the laborers who work for the industry while investing in the industrial facilities at urban sites. Those people were forced to solve their housing problems by building illegal houses on public state-owned land. The legitimization of those areas through reconstruction remissions supported the redistribution of urban lands. (Ataov, Osmay, 2007).

Starting from the 1950s, the population of squatter houses was considered to be a positive contribution to the economy. (Erman and Eken, 2004).

In the 1970s, there was a co-operation between the state and illegal housing producers. This co-operation can be read from the providing services such as electricity, water, infrastructure and transportation to the squatter houses by the government. This co-operation resulted in the placement of squatter houses in urban areas being taken for granted. Together with this process, it can be said that squatters see themselves as members of the urban community.

Granting amnesties to reconstruction and granting ownership rights to squatters during the 1980s can be considered as a tantalization of low-income groups. This production of space, which brought non-commodified areas into the property market, brought about new forms of inequal- ity rather than diminishing them. (Cavusoglu, 2014).

The 1980s can be defined as the period when urban rent market became dominant and income inequality became more visible. However, urban transformation movement started with the increasing value of urban land and 1999 Marmara Earthquake. In today's Turkey, urban transformation is one of the most common forms of housing production. In the urban redevelopment process, the low-income groups move to the peripheral zones of the city under the affect of exclusionary economic conditions while the highincome groups move towards redeveloped, gated communities which are designed with high security and social facilities where they live together with the people who belong to the same social class. This means that people are evicted from the areas where they feel a sense of belonging by forced displacement. (Sen, 2008; Turkun, 2014).

With the effects of globalization, the tendency of national economies switched from industrial production to service delivery. With the support of foreign investments in real estate property and construction sector, urban redevelopment projects gained momentum. (Yalcintan et al, 2014; Sen, 2008).

\section{Case Study}

\section{Study Site}

Sarigol is a settlement area in the Gaziosmanpasa district of Istanbul, which is very close to 2. Highway and 2. Bosphorus Bridge. Consisting mainly of illegally produced, low-rise shanty houses and residents from the low-income social classes, Sarigol was formerly a rural area with its income rooted in agriculture in 1935; however, the migration of the Roman community displaced in 1950 s and the migration of the Yugoslavian community after 1954 allowed the illegal housing developments to gain momentum. The intense immigration from rural areas to Istanbul in the 1980s brought a rise in population in the Gaziosmanpasa district. The development of illegal housing was accelerated through increasing accessibility of the area with the construction of the second bridge and the Tem highway in 1988. Thus, shantytowns such as Sarigol started to be seen as problematic areas of the city in the 2000s, because of their unplanned structure and insufficiency in meeting the needs of residents, aside from being mere shelter (Fig. 1 and 2).

Due to the rising crime rate, the earthquake risk, deteriorated housing conditions and high demand for rent; Sarigol was officially declared as a risky area in 2012. In 2014, just before the demolitions, the social fabric of Sarigol was made up of Roman citizens and Balkan immigrants. (Gaziosmanpasa Municipality Report, 2014) Limited access to education facilities and the lack of permanent job opportunities compelled the youth in the neighborhood to resort to illegal ways of making earnings. Thus, the 


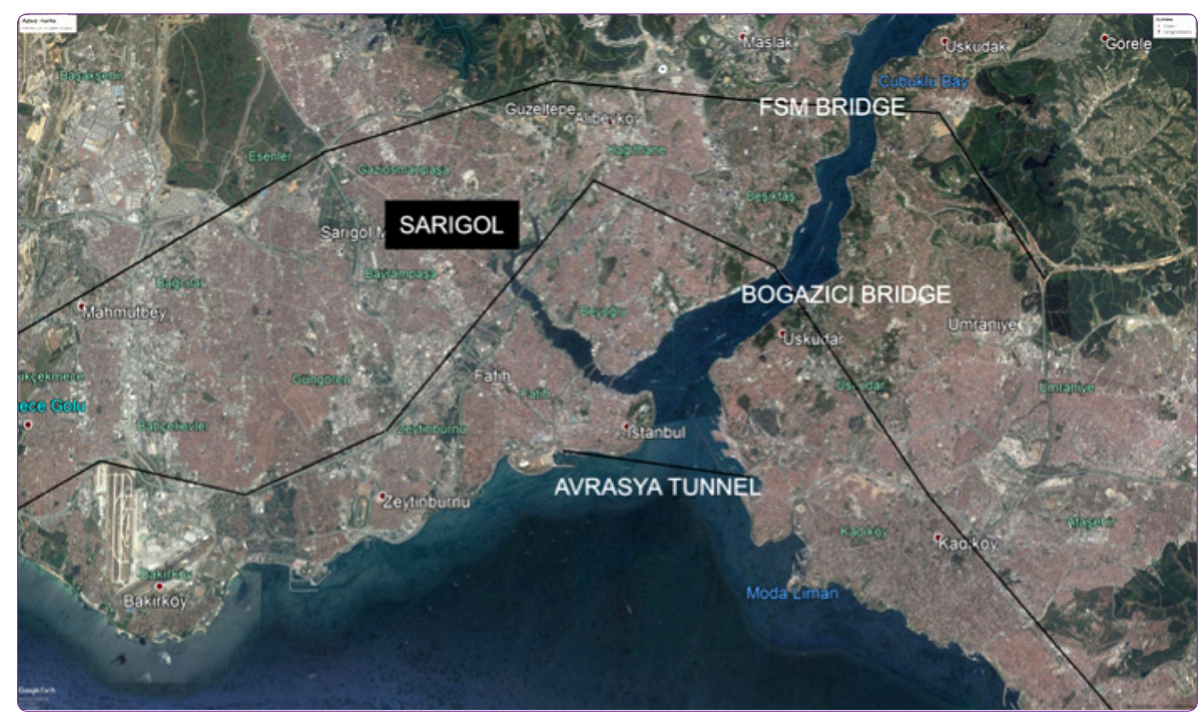

Figure 1. The location of Sarigol in Istanbul. (Highways- Bridges) (GoogleEarth).

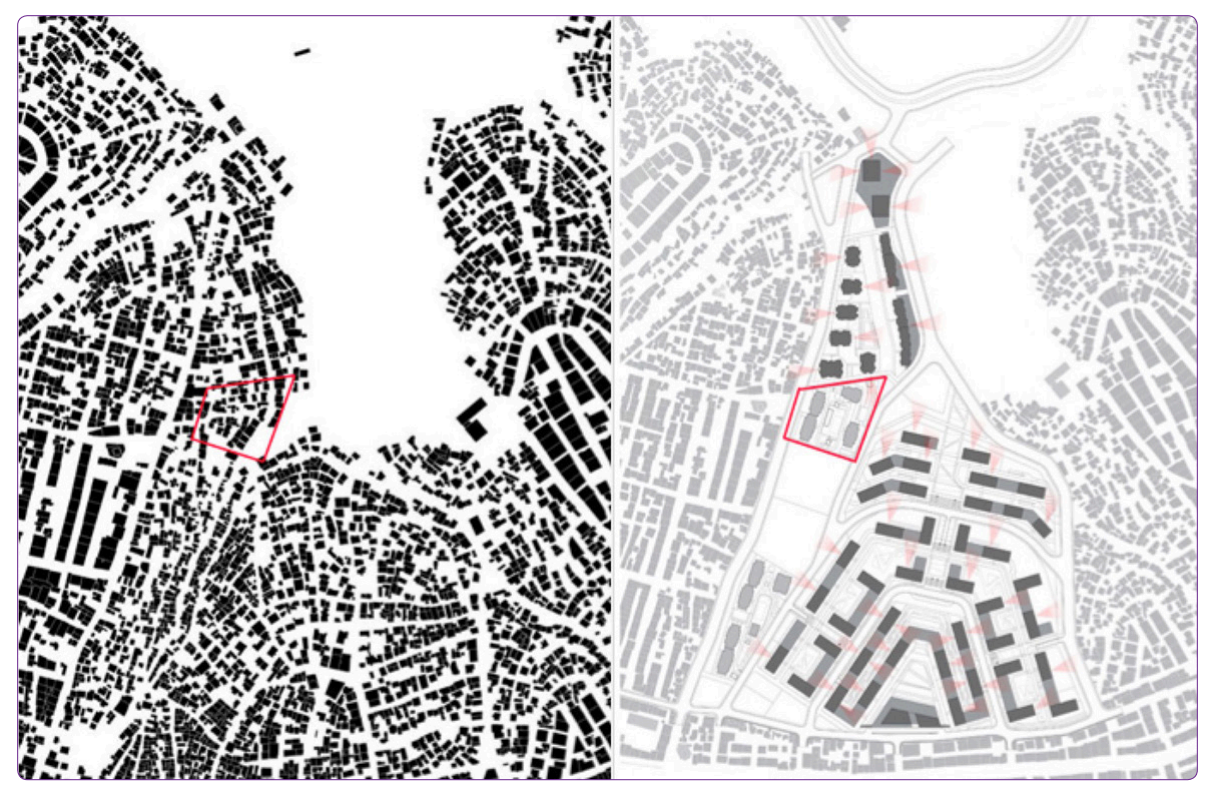

Figure 2. Changing in texture, Sarigol Housing Redevelopment Site (Gaziosmanpasa Municipality, 2014).

level of drug sales and drug use in the neighborhood rose above the levels of other districts of Istanbul and Turkey in general. This illegality propels crime in Sarigol and has negative impacts on the security of the lives of residents (Table 1).

The 256 structures, which existed before the process at the Sarigol Urban Transformation Site are 1 or 2 storey squatter houses which were mostly built in accordance with the masonry structure technique before 1980. (Gaziosmanpasa Municipality Report, 2014) The ownership rights of a total of 393 households, varied in terms of title holders and ownership certificate holders in the scope of the project. This difference led residents to either stay or be displaced, according to their economic situations.

\section{Method}

The data on Sarigol, used in the article, collected qualitative research. Academic references for our methodology are made below:

According to Adaman and Keyder's research titled, "Poverty and Social Exclusion in the Slum Areas of Large Cities in Turkey," the concept of social exclusion coincided with the lack of access to education, pushing residents to the margins of society due to social segregation, which kept them from participating in social life. Social exclusion is discussed as a multi-dimensional concept within the economic, political, cultural and spatial aspects. The case study was realized in three steps in the qualitative and quantitative dimensions. In the first step, 34 semi-struc- 
Table 1. User Groups Indicators in Sarigol Redevelopment Site

\begin{tabular}{|c|c|c|c|}
\hline & \multicolumn{3}{|c|}{ User Profile } \\
\hline & Stabiles & Departers & New Comers \\
\hline Educational status & Primary school graduate & Primary school graduate & University graduate \\
\hline Monthly housing income & Approximately $2000 \mathrm{TL}$ & $2000-5000 \mathrm{TL}$ & $2000-5000 \mathrm{TL}$ \\
\hline \multirow[t]{2}{*}{ Ownership of housing } & Current housing (100\%) & Current housing (73\%) & Current housing (81\%) \\
\hline & Previous housing (100\%) & Previous housing (64\%) & Previous housing (78\%) \\
\hline Professional status & Retiree & Retiree & Salaried employee \\
\hline Previous period of residency & More than 20 years & More than 20 years & $\begin{array}{l}\text { 1-5 years: } \% 41 ; 5-10 \text { years: } \\
\% 24 ; 10-20 \text { years: } \% 13 ; \\
\text { more than } 20 \text { years: } \% 22\end{array}$ \\
\hline Current housing expenses & $100 \%$ increased & $\begin{array}{c}\text { Increased: \%46; not changed: } \\
\quad \% 27 ; \text { decreased: } 27\end{array}$ & $\begin{array}{c}\text { Increased: \%76;not changed: } \\
\quad \% 11 ; \text { decreased: } \% 13\end{array}$ \\
\hline
\end{tabular}

tured, in-depth interviews were conducted with a sample, which consisted of agents from non-governmental organizations (NGOs) and academicians, including 12 focus group interviews. In the third step, a questionnaire was given to 1,863 residents living in shantytowns. (Adaman and Keyder, 2006).

According to research by Aktas Yamanoglu titled, "Living Conditions of Urban Poor Youth and the Reproduction of Poverty," the study was built on social exclusion, due to economic distinctions. The case study was a qualitative research conducted in the form of 65 semi-structured, indepth interviews with people between 15-and-29-yearsof-age living in Ankara's shantytowns. (Aktas Yamanoğlu, 2006).

Gustafson's study aimed to build an analytical framework for meaning attachment to specific places. The study was carried out as a two-stage qualitative analysis. Respondents were asked about the meanings that they attached to places, which they consider important. The qualitative data derived from semi-structured, in-depth interviews conducted on a sample group of 14 people. In this study, Gustafson applied Trost's methodology of strategic, nonrepresentative sampling. The objective of Gustafson's approach was to gain a diversified amount of variation in the responses about the phenomenon being studied. The result of these interviews revealed that the immediate meanings attached to places by the respondents are related to the concepts of self, others and the environment. (Gustafson, 2008).

In prelude, knowledge of the redevelopment process was enhanced as a result of the foregoing literature review. In the scope of the new information, the semi-structured, in-depth interviews were conducted on 20 people who showed various types of housing mobility and were formed under seven factor groups based on the analysis of studies conducted during the literature review, as well as the collection of the parameters that were valid for the Sarigol sample. The factors included the physical features of housing, comfort conditions, physical environment features, environmental factors, security opportunities, social environment features and user profiles. Conducting indepth interviews was considered to be an ideal method for analyzing the transformation within the context of the neighborhood, since qualitative research enables respondents to reveal their opinions willingly without any restrictions. (Devine, 2002).

From October 2015 to July 2016, 16 face-to-face interviews were conducted at different frequencies and 4 phone interviews were held with the people who had moved out of town. The semi-structured, in-depth interviews were designed according to information derived from the literature review.

Using small samples and conducting each interview for a minimum of one hour were crucial factors in increasing the depth of the research. During the interviews, qualitative research questions were directed as open-ended questions to the inhabitants. As a result, data was collected regarding how participants understand the concepts of social belonging, displacement and social exclusion; how they conceptualize those concepts and how they evaluate these concepts (Greasley and Ashworth, 2007) In-depth interviews were extensively analyzed and the respondent's opinions on social belonging, displacement and social exclusion - the concepts that formed the conceptual framework of the article - were analyzed through content analysis.

Within the scope of the research, the inhabitants in the neighborhood were classified in three groups according to their housing mobility types; namely, "Stabiles, Departers and Newcomers." 
The group, which is categorized as "stabiles", constituted 38 percent of residents. Stabiles preferred to stay in the neighborhood in the context of their socio-economic conditions. This group feels a sense of belonging to the neighborhood and they usually have titles to their homes. As an advantageous group during the redevelopment process in terms of ownership rights, they feel socio-economically ready to live in newly built homes.

The group, which is classified as "departers", makes up 16 percent of residents. Departers decided to leave amid fears that they would not fit in with the new fabric of the neighborhood socio-culturally, economically and physically. This group is disadvantageous in terms of ownership rights, as they either have ownership certificate or they are tenants. Unable to fulfill such economic requirements as rising rent in new apartments built during the redevelopment process, tenants were the first displaced group. The residents who hold ownership certificates were also involuntarily displaced because they cannot afford the difference between expropriated prices of their homes and the price of new homes.

The group, which is defined as the "newcomers", makes up 46 percent and shows voluntary housing mobility because of the physical features of the neighborhood such as the security provided by the gated community, playgrounds for children, parking garages and conditions for physical comfort. This group aimed to have better living conditions and higher quality of life by moving to the neighborhood.

\section{Data Analysis}

Within the context of the three concepts of this article; namely, the sense of belonging, displacement and social exclusion, the in-depth interviews were analyzed, interview transcripts were read a number of times and compared with existing literature. In this section, the comparison is shown between the conceptual framework compiled from the literature and the responding statements. In the tables below, the comparison between the literature review and in depth interviews were monitored. Content analysis was conducted on the recordings of the interviews of the respondents number between 1-20.

\section{Social Belonging}

Above, knowledge of the literature review and statements from the interviews were matched. Statements from the in depth interviews on social belonging can be presented as follows (Table 2):

\section{-Social Belonging}

i.A (66) clarified his neighborhood satisfaction with his social network as he could easily communicate with his friends and relatives. However, he no longer feels a sense of belonging to the new social fabric of the neighborhood. He described his dissatisfaction as:
"There is no vicinage within the neighborhood anymore... You can't tell who enters the building, many people moved here recently..." (February 12, 2016).

i.i. (71) who sells bread in Sarigol for many years told that some of his relatives and friends were displaced and their social networks have been destroyed. He said:

"Old friendships no longer exist, neighborhood environment was destroyed, everyone dispersed, now there in no one to talk... Nowadays, it is really hard to get together." (Interview dated November 5, 2015).

O.M. (29), as a newcomer, explained their disjointedness within the neighborhood as:

"I believe that the new system will be on the right track slowly. Right now, the environment is quite unsafe; we hope that the surrounding neighborhoods also transform and the unsafe environment becomes safe. We hear many gun shots, scrimmage and screaming at nights. We hope that these people will be detached from this neighborhood."

Through these words, he explained that he feels satisfied with his new house; however, he is unsatisfied with the social environment. (Interview dated October 6, 2015).

H.G. (42) is an employee of a private company and moved to the neighborhood during the redevelopment process. He stated that he prefer to live here since it is a gated community however, he thinks that the neighborhood environment is quite unsafe.

"The neighborhood is in the city center but crowded and noisy. We hear gunshots and noises from the houses near us. They are selling drugs to whole Istanbul... I find here unsafe, how could I feel safe in here? I hope it will get better..." (Interview dated November 5, 2015).

\section{Displacement}

Knowledge of the literature review and statements from the interviews were related with regard to the concept of displacement. Statements from the in depth interviews on displacement presented as follows (Table 3):

\section{- Displacement}

B.N. (46) moved to another neighborhood because he had an ownership certificate for his house in Sarigol and he had limited economic conditions. He explained his disjointedness with the new neighborhood as:

"I am selling furniture, my monthly income is around 1200-1500 Turkish Liras, sometimes it reaches 2000 TL.... I've chosen to receive the amount that I deserve because I thought that I could not pay for the new house. I am living a cheaper neighborhood now. I guess eventually we will get used to this new neighborhood, its people..." (Interview dated November 26, 2015).

However, even though he feels a little sense of belonging to his new social environment, he has an expectation of conformance. 
Table 2. Table showing the content analysis of the statements about social belonging in the literature and in in-depth interviews

\begin{tabular}{|c|c|c|c|c|c|c|c|c|}
\hline & & $\begin{array}{c}\text { Hummon, } \\
1992[4]\end{array}$ & $\begin{array}{c}\text { Savage, et al., } \\
2010 \text { [3] }\end{array}$ & $\begin{array}{c}\text { Simonsen, } \\
2008 \text { [1] }\end{array}$ & $\begin{array}{c}\text { Gustafson, } \\
2008 \text { [2] }\end{array}$ & $\begin{array}{l}\text { Lewicka, } \\
2011 \text { [6] }\end{array}$ & $\begin{array}{l}\text { Fallov, et al., } \\
2013 \text { [7] }\end{array}$ & $\begin{array}{c}\text { Pinkster and } \\
\text { Boterman, } \\
2017 \text { [9] }\end{array}$ \\
\hline & GROUP & $\begin{array}{l}\text { Existing } \\
\text { relations } \\
\text { between site, } \\
\text { its residents } \\
\text { and their } \\
\text { mobility }\end{array}$ & $\begin{array}{l}\text { SOB shapes } \\
\text { in parallel } \\
\text { with social } \\
\text { distinctions } \\
\text { and variations }\end{array}$ & $\begin{array}{l}\text { Place as } \\
\text { on-going and } \\
\text { contextual } \\
\text { process }\end{array}$ & $\begin{array}{c}\text { Mobility } \\
\text { and SOB } \\
\text { is not } \\
\text { differential }\end{array}$ & $\begin{array}{l}\text { Meanings } \\
\text { of stories } \\
\text { and traditions } \\
\text { that people } \\
\text { attach to } \\
\text { certain places }\end{array}$ & $\begin{array}{c}\text { Between } \\
\text { sense of } \\
\text { social } \\
\text { belonging } \\
\text { and length } \\
\text { of } \\
\text { inhabitancy }\end{array}$ & $\begin{array}{l}\text { Familiarity } \\
\text { with the } \\
\text { neighborhood } \\
\text { and neighbors }\end{array}$ \\
\hline INT. 1 & STABILES & $\checkmark$ & & $\checkmark$ & $\checkmark$ & $\checkmark$ & & $\checkmark$ \\
\hline INT.2 & STABILES & & & $\checkmark$ & $\checkmark$ & $\checkmark$ & $\checkmark$ & $\checkmark$ \\
\hline INT. 3 & NEW COMERS & & & $\checkmark$ & $\checkmark$ & & & $\checkmark$ \\
\hline INT. 4 & NEW COMERS & $\checkmark$ & $\checkmark$ & $\checkmark$ & & $\checkmark$ & & $\checkmark$ \\
\hline INT. 5 & DEPARTERS & $\checkmark$ & & $\checkmark$ & $\checkmark$ & & $\checkmark$ & \\
\hline INT.6 & DEPARTERS & & & & $\checkmark$ & $\checkmark$ & & $\checkmark$ \\
\hline INT.7 & DEPARTERS & $\checkmark$ & & & & & $\checkmark$ & \\
\hline INT. 8 & DEPARTERS & & $\checkmark$ & & $\checkmark$ & $\checkmark$ & & \\
\hline INT. 9 & STABILES & $\checkmark$ & & & $\checkmark$ & $\checkmark$ & $\checkmark$ & $\checkmark$ \\
\hline INT. 10 & STABILES & & & $\checkmark$ & & & & \\
\hline INT. 11 & DEPARTERS & $\checkmark$ & & & & $\checkmark$ & & \\
\hline INT. 12 & STABILES & & $\checkmark$ & $\checkmark$ & & & & $\checkmark$ \\
\hline INT. 13 & NEW COMERS & & $\checkmark$ & $\checkmark$ & $\checkmark$ & & & $\checkmark$ \\
\hline INT. 14 & NEW COMERS & $\checkmark$ & & $\checkmark$ & $\checkmark$ & & & $\checkmark$ \\
\hline INT. 15 & NEW COMERS & $\checkmark$ & $\checkmark$ & $\checkmark$ & & $\checkmark$ & & $\checkmark$ \\
\hline INT. 16 & STABILES & & & $\checkmark$ & $\checkmark$ & $\checkmark$ & $\checkmark$ & $\checkmark$ \\
\hline INT. 17 & STABILES & & $\checkmark$ & $\checkmark$ & & & $\checkmark$ & $\checkmark$ \\
\hline INT. 18 & DEPARTERS & & & & $\checkmark$ & $\checkmark$ & & $\checkmark$ \\
\hline INT. 19 & STABILES & & & $\checkmark$ & & & $\checkmark$ & \\
\hline INT. 20 & NEW COMERS & & $\checkmark$ & & & & & $\checkmark$ \\
\hline
\end{tabular}

K.K. (63) was living as a tenant in an apartment building in Sarigol for 5 years before the redevelopment. He moved somewhere close since his house had to be demolished. I met him in a local coffee shop in Sarigol; therefore, he still continues to have ties with his old community. K.K. pointed out that he lives in another neighborhood for 3 years, has no income, he's been able to live with the help coming from his children and his expenses aren't changed in new neighborhood.

"I wish I could live in the newly built houses but I have no income. Landlords demand too much money, there are dues but my conditions are insufficient." (Interview dated November 5, 2015).

F.S. (55) expressed that he was living in a house, which is a family inheritance and after the redevelopment, he moved to another house in Sarigol as a tenant. He said that his expenses increased with housing mobility; however, since his old house was too old and dilapidated, he actually feel satisfied with the new house.

"We have an ownership certificate, we are four broth- ers and everybody received his share. Municipality gave us 100.000 Turkish Liras in total..." (Interview dated November 22, 2015).

S.Y. (55) resided in Sarigol for approximately 50 years; however, he decided to move back to his hometown after getting his expropriated price.

"Kids got married, me and my wife remained. In this situation, we decided to go back to our hometown because it's peaceful and calm. We are comfortable in here, have a large garden, we are cultivating. Of course we miss our neighbors, still there is also very nice people here. But we miss the old days..." (Interview dated November 26, 2015)

During the interview, he stated that he feel satisfaction from the physical conditions of his new house and social environment, but he added that he misses the social environment conditions in Sarigol.

\section{Social Exclusion}

Above, knowledge of the literature review and statements from the interviews were linked together. State- 
Table 3. Table showing the content analysis of the statements about displacement in the literature and in in-depth interviews

\begin{tabular}{|c|c|c|c|c|c|c|c|c|}
\hline & & $\begin{array}{l}\text { Marcuse, } \\
1986 \text { [28] }\end{array}$ & $\begin{array}{l}\text { Newman and } \\
\text { Wyly, } 2006[58]\end{array}$ & $\begin{array}{l}\text { Lees and Ley, } \\
2008 \text { [10] }\end{array}$ & $\begin{array}{c}\text { Kleit, } \\
2010[18]\end{array}$ & $\begin{array}{c}\text { Bridge, Butler, } \\
\text { and Lees } \\
2012[14]\end{array}$ & $\begin{array}{l}\text { Tieskens and } \\
\text { Musterd, } \\
2013 \text { [13] }\end{array}$ & $\begin{array}{c}\text { Manzo, } \\
2013 \text { [19] }\end{array}$ \\
\hline & GROUP & $\begin{array}{l}\text { Ethnic, } \\
\text { racial and } \\
\text { income } \\
\text { segment } \\
\text { groups }\end{array}$ & $\begin{array}{l}\text { Exclusionary } \\
\text { effect of } \\
\text { market } \\
\text { conditions }\end{array}$ & $\begin{array}{c}\text { Mobility } \\
\text { of middle } \\
\text { income } \\
\text { groups to low } \\
\text { income } \\
\text { neighbor- } \\
\text { hoods }\end{array}$ & $\begin{array}{l}\text { Negative } \\
\text { effects on } \\
\text { housing } \\
\text { satisfaction } \\
\text { and the social } \\
\text { bonds within } \\
\text { the neighbor- } \\
\text { hood }\end{array}$ & $\begin{array}{l}\text { Critique } \\
\text { of stateled } \\
\text { urban } \\
\text { redevelop- } \\
\text { ment } \\
\text { projects }\end{array}$ & $\begin{array}{l}\text { Deterioration } \\
\text { of social } \\
\text { fabric }\end{array}$ & $\begin{array}{c}\text { Negative } \\
\text { effects on } \\
\text { housing } \\
\text { housing }\end{array}$ \\
\hline INT. 1 & STABILES & & & & & & & \\
\hline INT.2 & STABILES & $\checkmark$ & & & & $\checkmark$ & $\checkmark$ & $\checkmark$ \\
\hline INT. 3 & NEW COMERS & $\checkmark$ & & & & & $\checkmark$ & \\
\hline INT. 4 & NEW COMERS & & & & & & & \\
\hline INT. 5 & DEPARTERS & $\checkmark$ & $\checkmark$ & & $\checkmark$ & $\checkmark$ & & \\
\hline INT.6 & DEPARTERS & $\checkmark$ & $\checkmark$ & & $\checkmark$ & $\checkmark$ & $\checkmark$ & $\checkmark$ \\
\hline INT.7 & DEPARTERS & $\checkmark$ & $\checkmark$ & & & & $\checkmark$ & \\
\hline INT. 8 & DEPARTERS & $\checkmark$ & & & $\checkmark$ & & & $\checkmark$ \\
\hline INT. 9 & STABILES & $\checkmark$ & & $\alpha$ & & & & \\
\hline INT. 10 & STABILES & $\checkmark$ & $v$ & $\checkmark$ & & & & \\
\hline INT. 11 & DEPARTERS & $\alpha$ & $v$ & & & $\checkmark$ & $\checkmark$ & \\
\hline INT. 12 & STABILES & & $v$ & $\alpha$ & & & & \\
\hline INT. 13 & NEW COMERS & & & & & & & \\
\hline INT. 14 & NEW COMERS & & & & & & & \\
\hline INT. 15 & NEW COMERS & & & & & & & \\
\hline INT. 16 & STABILES & $\alpha$ & $v$ & $\alpha$ & & & & \\
\hline INT. 17 & STABILES & & & & $v$ & & $\checkmark$ & $\checkmark$ \\
\hline INT. 18 & DEPARTERS & $\alpha$ & $v$ & & 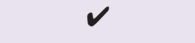 & $\checkmark$ & $\checkmark$ & $v$ \\
\hline INT. 19 & STABILES & $\alpha$ & & & $\checkmark$ & & $\checkmark$ & $\checkmark$ \\
\hline INT. 20 & NEW COMERS & & & & & & & \\
\hline
\end{tabular}

ments from the in depth interviews on social exclusion exhibited as indicated below (Table 4).

- Social exclusion

A.T (74) who first came to Sarigol as a bride at 16 years old expressed that she literally spent her whole life in Sarigol. She told their problems within the adjustment period as:

"We had a house with garden, we used to gather under the trees, wash the carpets... Now we don't even have a place to hang out our laundry, they do not allow to hang out at the balcony." (Interview dated October 22, 2015).

B.A. (43) who is a coffee shop owner in the neighborhood pointed out that they do not have an economically convenient market place to buy groceries as follows:

"There is only this place over there, but the owner sells whatever he wants. We don't shop from there, we go to upper neighborhood both for the market place and for daily needs..." (Interview dated November 5, 2015).
S.A. (42) who earns his living through shoe making moved to another house in a surrounding neighborhood during the redevelopment process. He stated that he is living in a same environment but the moving process was economically difficult.

"Here is also very calm... It can never be like our old house because we had a garden, we had our own place... But it was too bad to move, because we got into debt... It is a new environment, we are trying to get use to here..." (Interview dated November 22, 2015).

V.O.A (55) who is a "Stabile", told that he feel belonging to the neighborhood but housing expenses increased too much.

"We don't know our neighbors anymore, we can't let our children to play outside... Of course there is order now, we have security but you never know what he is doing... I don't consider leaving, I won't move somewhere else but it is not easy to stay either. Everyone wishes different things, they got annoyed of us." (Interview dated November 22, 2015). 
Table 4. Table showing the content analysis of the statements about social exclusion in the literature and in in-depth interviews

\begin{tabular}{|c|c|c|c|c|c|c|c|}
\hline & & $\begin{array}{l}\text { Power and } \\
\text { Wilson, } \\
2000 \text { [24] }\end{array}$ & $\begin{array}{l}\text { Atkinson, } \\
2000 \text { [30] }\end{array}$ & $\begin{array}{l}\text { Freeman and } \\
\text { Braconi, } \\
2004 \text { [32] }\end{array}$ & $\begin{array}{c}\text { Robila, } \\
2006 \text { [26] }\end{array}$ & $\begin{array}{c}\text { Bossert, } \\
\text { et al., } \\
2007 \text { [25] }\end{array}$ & $\begin{array}{c}\text { Slater, } \\
2009 \text { [29] }\end{array}$ \\
\hline & GROUP & $\begin{array}{l}\text { Disconnection } \\
\text { between residents, } \\
\text { social relations } \\
\text { and institutions }\end{array}$ & $\begin{array}{l}\text { Exclusionary } \\
\text { impact of } \\
\text { economic } \\
\text { conditions }\end{array}$ & $\begin{array}{l}\text { Exclusionary } \\
\text { impact of } \\
\text { economic } \\
\text { conditions }\end{array}$ & $\begin{array}{c}\text { Direct opposite } \\
\text { of social } \\
\text { integration }\end{array}$ & $\begin{array}{l}\text { Not continuing } \\
\text { their daily routine } \\
\text { activities in their } \\
\text { neighborhood }\end{array}$ & $\begin{array}{l}\text { Exclusion } \\
\text { of ethnic, racial } \\
\text { and income } \\
\text { segment groups }\end{array}$ \\
\hline INT. 1 & STABILES & $\checkmark$ & & & $\checkmark$ & & \\
\hline INT.2 & STABILES & & & & $v$ & $v$ & \\
\hline INT. 3 & NEW COMERS & & & & $\checkmark$ & & $v$ \\
\hline INT. 4 & NEW COMERS & $\checkmark$ & & & $\checkmark$ & & \\
\hline INT. 5 & DEPARTERS & & & & & & \\
\hline INT.6 & DEPARTERS & & & & & & \\
\hline INT.7 & DEPARTERS & & $v$ & & & & \\
\hline INT. 8 & DEPARTERS & & & & & & \\
\hline INT. 9 & STABILES & & & $v$ & $\checkmark$ & $\alpha$ & $v$ \\
\hline INT. 10 & STABILES & & $v$ & $v$ & & $v$ & $v$ \\
\hline INT. 11 & DEPARTERS & & $v$ & $\checkmark$ & & & \\
\hline INT. 12 & STABILES & $v$ & $v$ & & & & $v$ \\
\hline INT. 13 & NEW COMERS & & & & $\checkmark$ & & \\
\hline INT. 14 & NEW COMERS & & & & $v$ & & \\
\hline INT. 15 & NEW COMERS & & & & $v$ & & $v$ \\
\hline INT. 16 & STABILES & & $v$ & $\checkmark$ & & $\checkmark$ & $v$ \\
\hline INT. 17 & STABILES & & $\checkmark$ & $\checkmark$ & & $\checkmark$ & \\
\hline INT. 18 & DEPARTERS & & $\checkmark$ & & & & \\
\hline INT. 19 & STABILES & $v$ & $v$ & & $v$ & $\checkmark$ & $\checkmark$ \\
\hline INT. 20 & NEW COMERS & $\checkmark$ & & & $\checkmark$ & & \\
\hline
\end{tabular}

The relation between sociological concepts of different groups and findings from the data analysis showed in Table 5.

\section{Discussion}

The areas where squatter houses were first built in the 1950s became evident through their proximity to industrial sites and the protection of social bonds. (Turkun, 2014)
Therefore, it can be said that the main factor of squatter houses in terms of their existence is the social bonds that hold together the fabric of the neighborhood. However, in the 1960s the transformation from squatter homes to apartment blocks increased the density and changed the physical fabric in the neighborhood. By the 2000s, urban transformation had both changed the physical and social fabric of the neighborhood. The physical and social fab-

Table 5. Table showing the relation between the concepts and the groups who are classified according to their housing mobility

\begin{tabular}{llll}
\hline & SOCIAL BELONGING & DISPLACEMENT & SOCIAL EXCLUSION \\
\hline STABILES & $\begin{array}{l}\text { They feel a sense of belonging to the } \\
\text { old social and physical fabric. } \\
\text { Social networks were ruined because } \\
\text { their friends left. }\end{array}$ & $\begin{array}{l}\text { New economic conditions in the } \\
\text { neighborhood force them to leave. }\end{array}$ & $\begin{array}{l}\text { They ethnically and socio-culturally } \\
\text { excluded by the new comers. } \\
\text { They face social exclusion in }\end{array}$ \\
& $\begin{array}{l}\text { They miss the neighborhood. } \\
\text { They have compliance problems }\end{array}$ & $\begin{array}{l}\text { They left because their economic } \\
\text { opportunities were not sufficient. }\end{array}$ & There is no compliance problems in \\
& Thew neighborhoods.
\end{tabular}

within their new neighborhood.

They want stabiles to leave. 
ric's changes in the neighborhood can be explained as: the transformation of Gecekondus to gated communities and the exchange in socio-cultural structure. (Kurtuluş, 2008).

One of the main objectives of urban redevelopment projects is to reduce poverty rates and enhance the quality of life for residents of the neighborhoods. On the other hand, Tieskens and Musterd argued in their study that in some projects this objective turns into i) Demolition of squatter houses, ii) Forced displacement of residents, iii) Construction of housing which is shaped by the demands of middle-high income groups, iv) Mobility of middle-high income groups to the redevelopment site, v) Socio-culturally mixed course of life. (Tieskens and Musterd, 2013) As observed in the in-depth interviews, some difficulties arise in the process of living together, since the distinctions between social classes are very apparent in Turkey; as also Cavusoglu discussed. (Cavusoglu, 2014).

Residents face the oppression of being evicted according to their ownership rights (holding titles, ownership certificates or being tenants). During this process, tenants are usually the first group to be displaced. The residents who hold either titles or ownership certificates can only stay as long as they can afford the difference between the expropriated prices of their houses and the price of new homes. Residents with ownership certificates are generally forced to leave the site where they have lived for a long time, leaving behind the sense of belonging because they cannot afford the economic burdens. Thus, as Cavusoglu argued in his study, the redistribution of urban rent and ownership rights lead to the emergence of new inequality forms. (Cavusoglu, 2014).

In fact, voluntary or involuntary housing mobility comes along with problems such as, i) Disassociation from the neighborhood fabric and the loss of the sense of belonging, ii) Compliance-related problems at the new living site, iii) Divergence from social network, iv) Isolation and social exclusion. The impacts of class structures, ethnic and social exclusion were presented as the negative outcomes coming along with both the voluntary and involuntary displacement in the work of Clapham and Kintrea. (Clapham and Kintrea, 1984).

The prices of real estate properties in the neighborhood show an increase during the redevelopment process; therefore triggering a new process of displacement for the squatters who decided to stay after the process. (Marcuse, 1986) The exclusionary impact of market conditions on low-income groups during the urban redevelopment projects (including dues, limited shopping opportunities and et cetera,) is another dismissive threat. The exclusionary economic conditions affect stabiles and force them to indirect displacement. This is a crucial threat in terms of effecting the deterioration of the social fabric of the neighbor- hood.. (Newman and Wyly, 2006) The economic reasons of social exclusion can also be read from Aktas Yamanoglu's study in Ankara's shantytowns. (Aktas Yamanoğlu, 2006).

For those residents who resisted the impact of the new economic conditions and indirect displacement, it can be said that the level of physical comfort in the houses and the neighborhood are enhanced. (Atkinson, 2000) However, the socio-cultural environment they lived in, gave them a sense of belonging and allowed them to define themselves as part of a social network, disappeared during the process. (Freeman and Braconi, 2004) Thus, the neighborhood is no longer a place, which stabiles can feel sense of social belonging; the bonds between neighborhoods become weaker. This situation became clearly evident in the in-depth interviews made with "stabiles".

The transformation in the neighborhood's social fabric constitutes an impediment in terms of building new social bonds and a renewed sense of social belonging after the process. (Bailey et al., 2012) As observed in the field, this environment in the neighborhood creates a feeling of insecurity among residents. On the other hand, residents who decided to stay in new buildings, squatters who still live in untouched squatter houses and people who work illegally due to lack of social security are the most important dissatisfaction factors for "newcomers".

Newcomers primarily exclude stabiles with regard to their ethnicity; hence, the data coming from the field showed a parallelism with Slater's arguments. (Slater, 2009) The groups need a living area, which is shaped according to their cultural characteristics. Stabiles who were living in the neighborhood before redevelopment want to continue their daily habits; such as drying their laundry outdoors, socializing on the streets and visiting green areas. Those cultural characteristics and the negative impacts of redevelopment projects were both examined in Yilmaz's study in Tarlabasi, Turkey. (Yilmaz, 2008) Those circumstances have a negative impact on the sense of belonging for both stabiles who constantly receive warnings from the site management and newcomers who constantly complain in their statements about those habits.

\section{Conclusions}

In the 2000s, the urban transformation, which is supported by public policies, created negative outcomes regarding the physical and social aspects in the shantytowns of big cities. In some projects, even though the primary objective was in-situ transformation, the vulnerable groups in the neighborhood have to leave the site due to the exclusive effects of the process.

Leaving the area, people have a sense of belonging due to economic shortcomings is an important breaking point in the lives of squatters. After the process, the neighbor- 
hood is no longer the place known for its physical, social and economic fabric, which afforded people the sense of belonging. Stabiles who have problems with the changing economic and social fabric of the neighborhood had to live together with newcomers and with their exclusionary behaviors. Newcomers who moved to the new buildings because of their desire to have an improved quality of life also cannot adapt to the neighborhood due to their cultural and economic disparities with stabiles.

In the situation of in-situ transformation, problems such as exclusion, not feeling a sense of belonging and crime may arise because of the differences between stabiles and newcomers in terms of social exclusion, the lack of sense of belonging and crime. All those problems depend on the differences between social classes. The groups in the neighborhood cannot be integrated into each other after the process; therefore, they become alienated.

It is of importance that throughout the urban redevelopment process, social integration within the neighborhood has to be ensured. For this reason, urban redevelopment projects have to be planned according to financial, social and cultural characteristics of those areas.

Not only the physical but also the social fabric of the neighborhood must undergo innovative changes, taking into account important social bonds, to ensure that sociocultural and economic differences are overcome in order for the residents who decided to stay after the redevelopment process to be able to comply with the restrictions of the redeveloped area, allowing newcomers to gain a sense of belonging in the neighborhood. When vulnerable groups participate in economic life and have access to adaptation methods, they can live with other groups in harmony, considering the importance of providing social security and access to education in this point. In this way, social integration between stabiles and newcomers can be constructed more easily and the sense of social belonging can be reconstructed for all the groups of the neighborhood.

\section{References}

Adaman, F. and Keyder, C. (2006). "Türkiye'de Büyük Kentlerin Gecekondu ve Çöküntü Mahallelerinde Yaşanan Yoksulluk ve Sosyal Dışlanma." Retrieved March 16, 2017, from http:// ec. europa.eu/employment_social/spsi/docs/social_inclusion/2006/study_turkey_tr.pdf.

Adaman, F. and Keyder, C. (2006). ibid

Aktas Yamanoğlu, M. (2006). Consumer Culture and Turkish Poor Youths Identity: Issues of Vulnerability and Exclusion. Consumer Culture, Modernity and Identity,345-381. doi:10.4135/9789351507932.n13

Ataov, A. \& Osmay, S. (2008). A methodological approach to urban regeneration in Turkey. METU Journal of Faculty of Architecture, 24 (2), 57-82.

Atkinson, R. (2000). Measuring Gentrification and Displace- ment in Greater London. Urban Studies,37(1), 149-165. doi:10.1080/0042098002339

Bailey, N., Kearns, A., \& Livingston, M. (2012). Place Attachment in Deprived Neighbourhoods: The Impacts of Population Turnover and Social Mix. Housing Studies,27(2), 208-231. doi :10.1080/02673037.2012.632620

Bossert, W., Dambrosio, C., \& Peragine, V. (2007). Deprivation and Social Exclusion. Economica,74(296), 777-803. doi:10.1111/j.1468-0335.2006.00572.x

Bridge, G., Butler, T., \& Lees, L. (2012). Mixed communities: gentrification by stealth?Bristol: Policy Press.

Cavusoglu, E., (2014). ibid

Cavussoglu, E., (2014). Turkiye Kentlesmesinin Toplumsal Arkeolojisi, Ayrinti Press, Istanbul.

Clapham, D., \& Kintrea, K. (1984). Allocation Systems and Housing Choice. Urban Studies,21(3), 261-269. doi:10.1080/00420988420080531

Devine, F. (2002) 'Qualitative Methods'. In Marsh, D. \& Stoker, G. (Eds.) Theory and Methods in Political Science. New York: Palgrave Macmillan.

Erman, T., \& Eken, A. (2004). The "Other of the Other" and "unregulated territories" in the urban periphery: gecekondu violence in the 2000s with a focus on the Esenler case, Istanbul. Cities,21(1), 57-68. doi:10.1016/j.cities.2003.10.008

Fallov, M. A., Jørgensen, A., \& Knudsen, L. B. (2013). Mobile Forms of Belonging. Mobilities,8(4), 467-486. doi:10.1080/1 7450101.2013.769722

Freeman, L., \& Braconi, F. (2004). Gentrification and Displacement New York City in the 1990s. Journal of the American Planning Association,70(1), 39-52. doi:10.1080/01944360408976337

Fried, M. (1963). 'Grieving for a Lost Home' In Duhl, L. J. (1963). The urban condition; people and policy in the metropolis. New York: Simon and Schuster.

Gans, H. J. (1982). The urban villagers: group and class in the life of Italian-Americans. New York, NY: Free Press.

Gaziosmanpasa Municipality Report. (2014) ibid

Gaziosmanpasa Municipality Report. (2014) Retrieved May 6, 2017, from http://www.bing.com/cr?IG=C745357336C443B BA52A613E05C6735F\&CID=3033969E216566EE20809C6B20 6367D5\&rd=1\&h=VJm8m0IxduFVy88oFvojLcJHrxHRFubTdO U-q5_jTkY\&v=1\&r=http\%3a\%2f\%2fwww.gaziosmanpasa.bel. $\operatorname{tr} \% 2 f \& p=D e v E x, 5063.1$

Goetz, E. G. (2002). Forced Relocation vs. Voluntary Mobility: The Effects of Dispersal Programmes on Households. Housing Studies,17(1), 107-123. doi:10.1080/02673030120105938

Greasley, K., \& Ashworth, P. (2007). The Phenomenology of "approach to studying": The University Student's Studies within the Lifework. British Educational Research Journal, 33(6), 819-843.

Gustafson, P. (2008). ibid

Gustafson, P. (2008). ibid

Gustafson, P. (2008). ibid

Gustafson, P. (2008). Mobility and Territorial Belonging. Environment and Behavior,41(4), 490-508. doi:10.1177/0013916508314478

Hummon, D. M. (1992). Community Attachment: Local Sentiment and Sense of Place, In I. Altman \& S. Low (Eds.), Place attachment (pp. 253-278). New York: Plenum Press. 
Kleit, R. G. (2010). Draining ties: Tie quality versus content in lowincome women's social networks when displaced by redevelopment. Journal of Social and Personal Relationships,27(4), 573-588. doi:10.1177/0265407510363430

Kurtuluş, H. (2008), "Kentsel Donusumun Politik Ekonomisi”, Iktisat Dergisi, No: 499, 26-33.

Lees, L., \& Ley, D. (2008). Introduction to Special Issue on Gentrification and Public Policy. Urban Studies,45(12), 2379-2384. doi:10.1177/0042098008097098

Lewicka, M. (2011). Place attachment: How far have we come in the last 40 years? Journal of Environmental Psychology,31(3), 207-230. doi:10.1016/j.jenvp.2010.10.001

Manzo, L. (2013). Exploring the shadow side: Place attachment in the context of stigma, displacement, and social housing. In Manzo, L. C., \& Devine-Wright, P. (2013). Place attachment: advances in theory, methods and applications. London: Routledge.

Marcuse, P. (1986). 'Abandonment, gentrification and displacement: the linkages in New York City' In Smith, N., \& Williams, P. (1986). Gentrification of the city. Boston: Allen \& Unwin.

Newman, K., \& Wyly, E. K. (2006). ibid

Newman, K., \& Wyly, E. K. (2006). The Right to Stay Put, Revisited: Gentrification and Resistance to Displacement in New York City. Urban Studies,43(1), 23-57. doi:10.1080/00420980500388710.

Pinkster, F. M., \& Boterman, W. R. (2017). When the spell is broken: gentrification, urban tourism and privileged discontent in the Amsterdam canal district. Cultural geographies,24(3), 457-472. doi:10.1177/1474474017706176

Popay, J. (2008). Understanding and tackling social exclusion: final report to the WHO Commission on Social Determinants of Health from the Social Exclusion Knowledge Network. Geneva: WHO Commission on the Social Determinants of Health.

Power, A., \& Wilson, W. J. (2000). Social exclusion and the future of cities. London School of Economics and Political Science,
Centre for Analysis of Social Exclusion.

Robila, M. (2006). Economic pressure and social exclusion in Europe. The Social Science Journal,43(1), 85-97. doi:10.1016/j. soscij.2005.12.009

Savage, M., Longhurst, B., \& Bagnall, G. (2010). Globalization and belonging. London: Sage.

Sen, B. (2008). "Kentsel Donusum: Kavramsal Karmasa ve Neoliberalizm", Iktisat Dergisi, No: 499.

Sen, B. (2008). Ibid

Senyapili, T. (2007). Charting the "Voyage" of Squatter Housing in Urban Spatial "Quadruped", European Journal of Turkish Studies, Retrieved August 9, 2017 from www.ejts. org.

Silver, H. F. (2014). Social exclusion \& social solidarity: three paradigms. New Delhi: Critical Quest.

Simonsen, K. (2008). "Place as Encounters: Practice, Conjunction and Co-existence." In Barenholdt, J. O., \& Granas, B. (2008). Mobility and place: enacting Northern European peripheries. Aldershot, England: Ashgate.

Slater, T. (2009). Missing Marcuse: On gentrification and displacement. City,13(2-3), 292-311. doi:10.1080/13604810902982250

Tieskens, K. F., \& Musterd, S. (2013). Displacement and urban restructuring in Amsterdam; following relocatees after demolition of social housing. Urban Research \& Practice,6(2), 194-210. doi:10.1080/17535069.2013.808432

Tieskens, K. F., \& Musterd, S. (2013). ibid

Turkun, A. (2014). Mulk, mahal, insan: İstanbul'da kentsel dönüşüm. Sisli, İstanbul: Istanbul Bilgi Universitesi.

Yalcintan, M.C., et al, 2014, Istanbul Donusum Cografyasi, (eds) Bartu Candan, A., Ozbay, C., In Yeni Istanbul Calismalari: Yersiz, Havasiz, Mulksuz Kent, Metis Press. Istanbul.

Yilmaz, B. (2008). Entrapped in Multidimensional Exclusion: The Perpetuation of Poverty among Conflict-induced Migrants in an İstanbul Neighborhood. New Perspectives on Turkey,38, 205-234. doi:10.1017/s0896634600004982. 